\title{
Erratum to: Specialty fruit production in the Pacific Northwest: adaptation strategies for a changing climate
}

\author{
Laurie Houston $^{1} \cdot$ Susan Capalbo $^{1} \cdot$ Clark Seavert $^{1}$. \\ Meghan Dalton $^{1} \cdot$ David Bryla $^{1} \cdot$ Ramesh Sagili $^{1}$
}

Published online: 4 July 2017

C) Springer Science+Business Media B.V. 2017

\section{Erratum to: Climatic Change \\ DOI 10.1007/s10584-017-1951-y}

The article "Specialty fruit production in the Pacific Northwest: adaptation strategies for a changing climate," written by Laurie Houston, Susan Capalbo, Clark Seavert, Meghan Dalton, David Bryla, and Ramesh Sagili, was originally published electronically on the publisher's internet portal (currently SpringerLink) on 3 April 2017 without open access.

With the author(s)' decision to opt for Open Choice, the copyright of the article changed on 23 June 2017 to (C) The Author(s) 2017 and the article is forthwith distributed under the terms of the Creative Commons Attribution 4.0 International License (http://creativecommons. org/licenses/by/4.0/), which permits use, duplication, adaptation, distribution, and reproduction in any medium or format, as long as you give appropriate credit to the original author(s) and the source, provide a link to the Creative Commons license, and indicate if changes were made.

The online version of the original article can be found at http://dx.doi.org/10.1007/s10584-017-1951-y.

Laurie Houston

laurie.houston@oregonstate.edu

1 Oregon State University, Corvallis, OR, USA 